\title{
Private Label as a global trend of food networks for pricing policy optimization (case study of St. Petersburg)
}

\author{
Elena Gregova ${ }^{1}$, Victor Dengov ${ }^{2 *}$, Irina Tulyakova ${ }^{2}$, and Azer Mustafaev ${ }^{2}$ \\ ${ }^{1}$ University of Zilina, Faculty of Operation and Economics of Transport and Communications, 01026, \\ Zilina, Slovakia \\ ${ }^{2}$ SPBU, Department of Economics, 199034 Saint Petersburg, Russia
}

\begin{abstract}
The practice of creating Private Label by large food chains is a global trend. Such international and Russian retailers as Auchan, SPAR, Prisma, Okay, Lenta, etc. have these products of their own brand. However, this marketing policy is not used by all the players in this market. In the conditions of a protracted economic recession that began in Russia in 2014, even such a seemingly stable sector of the economy as grocery retail faced a decline in its trade. The main reason for the current situation is, of course, a significant, more than $15 \%$ in 5 years, fall in real disposable incomes of Russian households. At the same time, for certain groups of households (families with children, single pensioners, etc.), the poverty is still much higher. In such households, expenses for food take significantly more than half of their incomes. The heightened competition of retail chains for a shrinking budget of buyers pushes them to search for new models of pricing policy. This article explores the possibility of using the practice Private Label by food chains.
\end{abstract}

\section{Introduction}

Russia, without doubt, finds itself among the countries most seriously affected by the global economic recession. The recession there lasted significantly longer and the effect of it was significantly deeper compared to the countries of the EC. This time even such economic sectors as the food retail industry, telecommunications, residential construction etc., which normally tend remain relatively stable even in the periods of crisis, were seriously affected by the prolonged recession. The main reason for the current situation is, of course, a significant, more than $15 \%$ in 5 years, fall in real disposable incomes of Russian households. Even according to official figures, about 20 million people in Russia (13\% of the population) are below the poverty line now. According to the expert opinion, the poverty rate in Russia is approximately $25 \%$ (36 million people) [1]. At the same time, for some specific groups of households (families with children, incl. single-parent family, lonely elderly people, small town and rural citizens etc.) this figure is considerably higher. In such households, expenses for food take significantly more than half of their incomes.

\footnotetext{
*Corresponding author: v.dengov@spbu.ru
} 
After paying the house bills, they clearly do not have enough money for other needs. As a result, the debt load of the population is quickly growing, subsequently causing the further decrease of the real income. The credit resource market shows clear signs of the process of adverse selection [2], that leads to the deepening differentiation of income and impoverishment of the significant part of the population [3].

The heightened competition of retail chains for a shrinking budget of buyers pushes them to search for new models of pricing policy. In the first article of two-article cycle, the authors investigated problems of creating and improving "consumer loyalty programs", analysed the current situation in the St. Petersburg food retail market and offered their own model of trade margins. The chief source of the competitive advantage for the standard goods, including many types of the food products, is the pricing strategy. In the period of a recession, it should maximally adapt to the change in the real income of the population (through creation and development of the loyalty programs). One such effective measure to increase the consumer loyalty, and thus, preserve and even boost one's competitive position could be the optimization of the trading margin for the high-turnover high-margin goods. The inflow of new customers can compensate the inherent insignificant loss of profit.

Another method of developing an optimal pricing strategy could be the use of the private label. If the use of the private label follows the contractual model, the lowering of prices can occur due to the discount given by the supplier in compensation of the franchising royalties, which are part of its obligations for the private label provided by the retailer. If the company develops a private label through the vertical integration, the lowering of prices occurs due to the considerable lowering of the cost of the targetproducts. As a result, such products will gain the competitive advantage on the shop floors of the food retailers in the period of recession.

\section{Theoretical and empirical bases of research}

We found the theoretic and methodological basis for our research in the works of both national and international authors. The theoretic base for the analysis of the pricing models were the publications of Cyert \& Marsh, Argote \& Greve [4, 5]. The analysis of the problem of price strategies used the works and studies of Samuelson \& Marks [6], Landsg [7] and Schindler [8]. Selected issues of pricing sales were refined using publications Van Westendorp [9] and Hess \& Gerstner [10]. The methods for the evaluation of the product competitive ability learned from the work of Shpak et al. [11]. Changes in psychology and consumer behavior were taken into account on the basis of studying the works Becker [12], Thaler [13], Kahneman \& Tversky [14], Mirică [15]. In the analysis of the private label as a marketing category and the study of the methods of its use in the production cycle of the food retail chains, we relied on the works by Starov [16] and Spiridonova [17, 18].

As the empiric base for our research, we used the primary and secondary statistical and analytical information, related to the agenda of our studies. Part of this information we obtained from the official sources and Internet data portals [19-21], while the rest of it the authors gathered themselves through the survey of customers, retailers and suppliers and the study of the food retailers' catalogs [22].

\section{Private Labels as a marketing category and the method of its use in the production cycle of food retailers}

The practice of the creation of a private label for the sale of their products is currently quite popular among the food retailers, yet to tell that everybody uses it would be far from true. Before we go on to prove the potential effect of the implementation of this strategy for the optimization of prices and promotion of the customer loyalty, it is necessary to explore the 
private label as a marketing category and the method of its use in the production cycle of the food retail chains in some more depth.

The private label is an arrangement for selling a particular product under the retailer's brand. At that, the retailers can either produce the product in question themselves, or buy it from the third-party manufacturers, the sales and promotion of the product, however, are carried out by the retailer under its own brand [16]. If a retailer acts as a manufacturer of its private label, this production process is akin to the "vertical integration of production" [17]. If the target product of the private label of the retailer is provided by a third-party manufacturer, then this type of organization Private Label can be called a "trademark by contract". Thus, we can illustrate the workings of the private label as follows (fig.1)

Trademark by contract

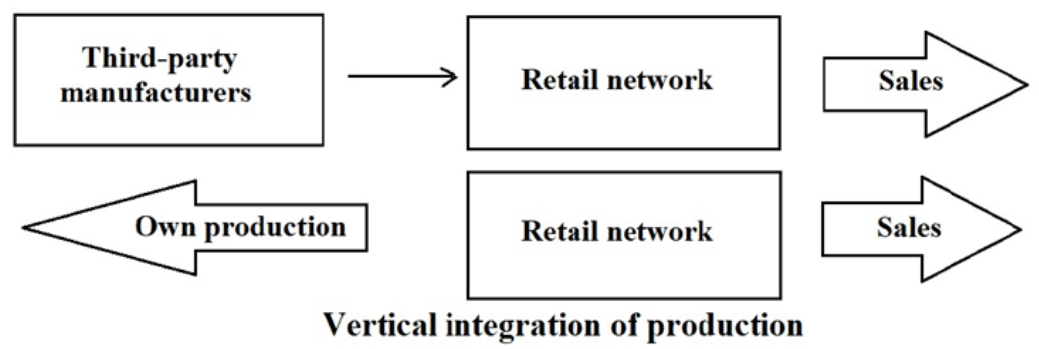

Fig. 1. Private Label mechanism of action in contracting and in the vertical organization of production

The most well-known examples of the implementation of the private label according to the contractual model are, for instance, the baby food, bakery and stationery products, sold under the $O^{\prime} K e y$ brand. As noted by Starov in his work, the private label is an effective means of marketing communications, especially for those manufacturers, who do not have much reputation in the market nor a firm positioning therein [16]. Therefore, the contraction with $O^{\prime} \mathrm{Key}$ and the sales of their production under the retail chain's label is for them a highly advantageous marketing approach.

By its nature, the private label is just an alternative way of marketing of the same food products. Potentially, though, it could be much cheaper, compared to a traditional method of buying the products from the suppliers. In the table 1, we present our own approach to the analysis of the private label as a tool for the optimization of the pricing strategy.

Table 1. Private Label as an optimal pricing strategy for individual interchangeable products

\begin{tabular}{|c|c|c|c|}
\hline \begin{tabular}{|c|} 
Model \\
Private Label
\end{tabular} & $\begin{array}{c}\text { Mechanism of the possible } \\
\text { price optimization }\end{array}$ & $\begin{array}{c}\text { Marketing } \\
\text { opportunities }\end{array}$ & Constraints \\
\hline $\begin{array}{l}\text { Trademark } \\
\text { by contract }\end{array}$ & \multirow{2}{*}{$\begin{array}{l}\text { Creating competition for } \\
\text { suppliers' products by } \\
\text { laying out Private Label } \\
\text { products with lower prices }\end{array}$} & \multirow{2}{*}{$\begin{array}{l}\text { Increasing } \\
\text { competitive } \\
\text { advantage and } \\
\text { increase } \\
\text { market share }\end{array}$} & $\begin{array}{l}\text { Inexpedient if the income from the sale of } \\
\text { the main suppliers of goods exceed the } \\
\text { revenues from the sale of goods Private } \\
\text { Label }\end{array}$ \\
\hline $\begin{array}{l}\text { Vertical } \\
\text { integration } \\
\text { of } \\
\text { production }\end{array}$ & & & $\begin{array}{l}\text { Impractical, if: } \\
\text { - the costs of organizing and conducting } \\
\text { production exceed the cost of procurement } \\
\text { - profit from the sale of goods of major } \\
\text { suppliers is higher than profit from the sale } \\
\text { of seller's Private Label goods }\end{array}$ \\
\hline
\end{tabular}

Thus, the decisive criterion for the use of the private label mechanism would be the economic benefits of its implementation: for a retail outlet, the net return from the introduction of the private label products should exceed the net return from the alternative (read - traditional) mode of distribution. Since the main competitive factor of the food 
products is their price, then, within the context of the pricing strategy optimization, the introduction of the private label mechanism should lead to lower prices for the respective products. In the period of recession, lower prices for the private label products can stimulate the demand for such products. The strength of the retailer's brand and relatively better quality of the product in comparison to other similar products could become the additional stimulating factors. At the same time, one should firmly understand that the implementation of the private label mechanism would be successful then, and only then, if the competitive advantages of the private label products are superior to similar products on sale. Therefore, the retailer-owner of the private label should introduce such products into the respective competitive field alongside other similar products bought from the suppliers (as Lenta, for instance, does in some of its outlets). If the private label product is able to meet the competition both in quality and price (has the optimal quality-price ratio), the competitive positions of such products will be higher than of those of the external suppliers, moreover, the brand of the retailer may create a stable demand for such products.

Here, it is also important to explain, why the sales of products through the private label arrangement is advantageous from the perspective of the optimization of the pricing strategies. The reason is simple: because such products can be cheaper, due either to the cheaper production or the lower wholesale price of the suppliers, who use the retailer's private label. In a graphic form, the mechanism of pricing strategy optimization through the private label could be presented as the following drawing (see fig. 2).

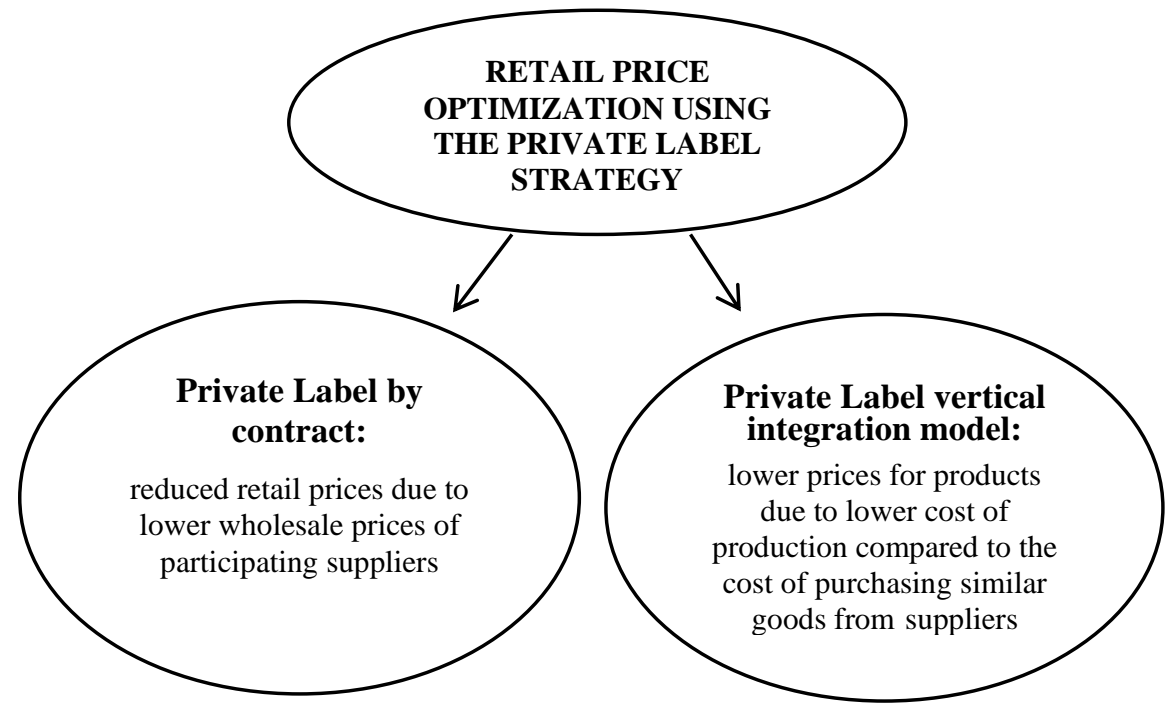

Fig. 2. Optimization retailer pricing policy for individual groups of products through the mechanism of Private Label

Thus, the key to the lowering of food products prices within the context of the private label model is the lowering of the primary cost of such products, while retaining the desired level of profitability. That would make it possible to, on the one side, keep the return of the company on the level desired by the chain-owners; and, on the other side, lower the prices, stimulate the demand for the products in question and strengthen the competitive positions.

What causes the lowering of the primary cost of the goods supplied by the manufacturers, who has agreed to sell their goods under the retailer's brand? Since the retailer undertakes the obligations for carrying out all the marketing communications and is in fact single effective distributor in the distribution channel of the goods of these suppliers, it can justly demand that supplier lowers the supply prices by the potential value of franchising royalty in the existing market environment. By providing its private label, the 
retailer actually employs the mechanism of the goods franchising, in the course of which it transfers the rights to the means of identification - a trademark or a trade name of a retailer - to the supplier within a license agreement. Since a private label also presupposes the carrying out of the marketing communications (i.e. promotion and sales), the brandpackage of the supplier widens into the business franchising - complete support of the product sales by the retailer [18]. Therefore, the supplier itself depends on the retailer and in the way of compensation, equivalent to the franchising royalty, may lower its supply price to this retailer. Thus, the primary cost of the product for the retailer becomes lower, and consequently the retail price of the product lowers as well.

It is necessary to point out that the contraction between the major retail chains and the little known in the market manufacturers is a mutually advantageous symbiotic model of co-operation between the two economic agents. The advantages for the retailer are clear and follow from the above-listed reasons. The advantages for the direct manufacturers is also understandable: for the little known suppliers with low sales and promotion budgets such a technology may be quite profitable on the first stages of the product sales. Thus, the private label arrangement with the little known suppliers with sufficient quality of product but weak market positioning is a potentially effective method for the optimization of the pricing strategy in the period of recession.

\section{The potential effectiveness of applying a private label strategy as part of price optimization}

The implementation of the private label according to the vertical integration model is more difficult, but also potentially advantageous in regards of certain groups of products. As rightly noted by Spiridonova [17], the vertical integration of the production is one of the ways toward the economic sovereignty for the business dependent on a certain value chain. Exploring this type of product manufacturing and sales within the context of pricing strategy optimization, we need to point out the economic viability criterion for the implementation of this measure: the vertical integration (i.e. the production of products directly by the retailer) under the proprietary trademark makes sense, if the business effect from the sales of such production exceeds the business effect from the sales of the production of the outside suppliers.

Currently, the Lenta hypermarkets actively use this practice by incorporating the bakery facilities into the structure of their sales outlets. Here, we can also see the serious limitation for the implementation of this method of the pricing strategy optimization: it is possible only in regards of such products that can be produced within the territory of the company itself. In effect, it is chiefly the bakery products. As other options, you can consider the preparation of salads and semi-finished meat products (such as minced meat, etc.).

Despite the certain difficulties and limitation, the production of such products can be more profitable than buying them from the suppliers and reselling. To prove this thesis, let us build a model of the organization of the most primitive bakery facilities in a single supermarket and compare the potential profits thereof to the profits from the sales of the bakery products bought from the external suppliers.

To begin with, let us define the assumptions and limitations of this model. In order to make our analysis universal, we will take the wheat and rye bread as the consumer goods, which one can potentially replace by the in-house bakery products. The trading margin for the bakery products in the retail shops of St. Petersburg does not exceed 30\% [20]. Presently, according to the catalogs of the three companies that are gradually losing their competitive positions (Polushka, O'Key and Lenta), the most favorite marks of bread bought from outside suppliers are as follows (see table 2). 
Table 2. Bakery products most in demand at target enterprises

\begin{tabular}{|l|c|c|c|}
\hline The product brand & $\begin{array}{c}\text { Price per } \\
\text { unit (rub.) }\end{array}$ & $\begin{array}{c}\text { Unit cost including } \\
\text { margins (rub.) }\end{array}$ & $\begin{array}{c}\text { Daily amount at full load } \\
\text { (pcs) }\end{array}$ \\
\hline Bread "Dvinsky" & 50 & 38.5 & 500 \\
\hline Bread «Borodinsky» & 50 & 38.5 & 120 \\
\hline Bread «Zernovoi» & 62 & 47.7 & 120 \\
\hline Long loaf "Molochny" & 49 & 37.7 & 120 \\
\hline
\end{tabular}

Source: Compiled by the authors based on catalogs of retailers: Catalogs goods supermarket chain "Okay" (Date of contact: April 2, 2019) Available at: https:/www.okmarket.ru/ customers/catalogs/; Catalog of supermarkets "Polushka" (Date of contact: April 2, 2019) Available at: http://www.a-piter. ru/cena/polushka skidki.html; Ltd. "Prism" - catalog (Date of contact: April 2, 2019) Available at: http://tomall.ru/allmarket/prisma

* The amount at maximum load was determined experimentally during the survey.

Since bread is a fully realizable product (the shops almost never have any excess stock), the daily proceeds of a supermarket that sells a given amount of bread items from bread alone will constitute 25,320 rubles, and the monthly proceeds will then be 759,600 rubles. The gross expenses of the supermarket within the context of the presented model can constitute 584,308 rubles, with the gross profit of 175,292 rubles. The monthly return on costs of the company from the sales of this product will be $29.9 \%(175,292: 584,308=$ $0,299)$. Thus, the implementation of the alternative measure, i.e. the vertical integration and organization of the in-house bakery facilities in the case of the same amount of sales (480 bread items a day, 14,400 items a month) should not be lower than this value. Let us calculate whether this is possible under the current market conditions.

The table 3 provides the expenses for the purchase of the basic equipment for the bakery facility inside a hypermarket. There we also introduce an assumption: since the facility takes up a part of the whole floor space of the hypermarket, the rental fee is ignorable. As the useful lifetime of the equipment, let us take the standard useful life of the furnace equipment -10 years with the straight-line basis of depreciation [21].

Table 3. Potential costs for the purchase of basic equipment in the organization of a small-sized bakery shop (rub.)

\begin{tabular}{|l|c|c|c|}
\hline Type of equipment & Estimated initial cost & Annual depreciation, & Monthly depreciation, \\
\hline Baking oven & 600000 & 60000 & 5000 \\
\hline Kneading machine & 250000 & 25000 & 2090 \\
\hline Proofing cabinet & 40000 & 4000 & 340 \\
\hline Dough cutting table & 40000 & 4000 & 340 \\
\hline Baking equipment & 43000 & 4300 & 360 \\
\hline
\end{tabular}

Source: Formed by authors based on: Revenues and expenses of a mini-bakery (Date of contact: April 4, 2019) Available at: http://biz911.net/organizatsiya-biznesa/dokhody-i-raskhody-biznesa/dokhody-iraskhody-mini-pekarni/

Thus, the monthly fixed costs for depreciation can constitute 8,130 rubles. With the volume of production 480 items a day, that will give us 0.56 rubles per item.

Since the company integrates the bakery facility into the retail space, we may assume that the company pays for the electric power, water supply and lighting of the entire hypermarket according to the agreed commercial tariffs. The personnel of the mini-bakery are two bakers, who also act as cashiers, with the average salary of 50,000 rubles (as per usual St. Petersburg rates according to the information of Trud.com) [19]). Thus, the fixed expenses on the wages fund per an item will constitute 6.9 rubles/item. For the expenses on the raw materials and supplies per an item, let us accept the figure provided by the $M K$ information resource -15 rubles/item [25]. Thus, the total cost of a bakery item for the facility itself can be 22.46 rubles. In view of the desired rate of return, the (average) price 
of a bread item will be 29.2 rubles, which can potentially make the customers have doubts concerning its quality (since the price is quite low). As a result, through raising the rates of return and, consequently, the trading margins, the company can not only preserve, but also raise its proceeds and profitability by selling the self-produced bread. For example, if one sets the average price of the self-produced bakery products, the form and ingredients of which are similar to those of the bread products, shown above as the favorite ones in the consumer basket, as 45 rubles, the return on cost of such a bread item will be $100.3 \%$, thrice more than the profitability ratio of the presented bread items According to the principle that one should avoid the round figures and balancing the price value between the acceptable price and the one, at which the consumer would avoid buying this product (Price Sensitivity Meter method - PSM [9]), one can set the average price of the bakery products at 43 rubles. The table 4 provides the comparative results of the sales following the private label model, and the ones, following the traditional model of buying the product from a supplier.

Table 4. Comparative indicators of income (RUB) and profitability (\%) of two approaches to the sale of bakery products

\begin{tabular}{|l|c|c|c|c|c|}
\hline & Price & Revenue & Total costs & Gross profit & ROC \\
\hline $\begin{array}{l}\text { Vertical integration of } \\
\text { production }\end{array}$ & 43 & 619200 & 324000 & 295200 & 91.1 \\
\hline $\begin{array}{l}\text { Buying goods from } \\
\text { suppliers and reselling }\end{array}$ & $49-62$ & 759600 & 584308 & 175292 & 29.9 \\
\hline
\end{tabular}

Thus, under the assumed conditions, the potential yield from the implementation of the vertical integration of the production can raise the profitability ratio by $61.2 \%$, lower the average price by $21.9 \%$ and increase the proceeds approximately by $68 \%$. For a retailer, especially in the current situation, such an increase will be a significant one.

At the same time, in the analysis of the practical viability of this model, one needs to take into the account a number of limitations inherent therein. Primarily, there is no guaranty that under the current conditions the self-produced products will sell in the same volumes as the ones of the competing labels, since no one can guaranty their high competitive ability. One of the factors limiting this competitive ability is, for instance, the fact that the new product would lack the stable reputation among the shopping consumers. In other words, there is some nonsystematic risk of the lack of sufficient effective demand for the presented product.

Secondly, a significant limitation is the high initial investment needed for the implementation of the project. According to the given estimate of the approximate expenditures on the purchase of the capital assets of the bakery, the company needs to invest 973 thousand rubles or more into the installation of all the necessary equipment, which means that the project of the organization of the in-house bakery will have a certain pay-off period. In view of the calculations made for this model, it takes 4 months.

Thirdly, since all the presented calculations rely on the simulation alone, one should take the initial variables, i.e. the prices of the resources and the direct expenses on raw materials and supplies per item, with a certain degree of conditionality. It is important to understand the average character of almost every value used in the analysis. Thus, the model may serve only as a vector of a potential development of the company towards the optimization of the pricing strategies.

Nevertheless, even despite the inherent limitations of the model, the presented calculation prove that the vertical integration of the production can be more effective than the traditional model of buying and reselling the goods, since it allows the company to considerably increase the proceeds, while simultaneously lowering the prices. It could be especially important in the situation of a prolonged recession, which is by definition longer 
than the potential pay-off period of the investments needed for the installation of the bakeries. The important bottom-line here is that as an optimization tool, the private label according to the vertical integration model can become an acceptable alternative to the traditional sales mechanisms.

It is also necessary to add that, depending on the size of the retail chain, the (partial or full) vertical integration could be also performed in regards of the other product categories (for instance, meat products), wherein it could also prove effective.

\section{Conclusions}

Due to the continuous decrease of the real incomes of the population and, as a consequence, of the commodity turnover, proceeds and profitability, the retail chains have to perfect their pricing strategies. Producing the goods under their own brand is another method thereof, beside the development of the customer loyalty programs and the optimization of the whole trading margins system.

The use of private label is an alternative way of selling the same food products, yet potentially - a cheaper one in comparison to the traditional mechanism of buying goods from the external suppliers $[27,28]$. The goods sold under the private label of the retailer can be produced either by the independent manufacturers according to the franchising agreement, or by the retail chains themselves directly on the sales floor [29, 30]. Both methods have their own advantages, disadvantages and limitations. A significant limitation for the second method is that there are only relatively few products, which the retailer can produce in the in-house facilities directly at the hypermarket. Primarily, we are speaking about the bread and bakery products, various salads and convenience meat products. On the other hand, in view of the considerable weight of these product groups in the retailers' turnover, this method also cannot be ignored.

Using the real data, obtained from the various information portals, we calculated the possible lowering of prices, if the retail chains integrate into their sales floors minor production facilities, bearing in mind the value of the expenses, generated operating profits, proceeds and profitability ratios.

\section{References}

1. Finance Rambler. Available at: https://finance.rambler.ru/ economics/39808105bednost-v-rossii-desyatki-millionov-za-chertoy/?utm_source=head\& utm_medium=news\&utm_content=news\&utm _ campaign=self_prom (2019)

2. V. Dengov, E. Melnikova, Adverse Selection on Credit Markets: The Analysis of the Empirical Research Results. Proceeding of the 7th International Conference on Currency, Banking and International Finance. Bratislava, Slovakia, 38-52 (2012)

3. V. Dengov, E. Gregova, Social inequality in community and ways (or mechanisms) of its overcoming. Ekonomicko-Manažérske Spektrum, 1, 63-73 (2012)

4. R. Cyert, J. Marsh, A Behavioral Theory of the Firm. Wiley-Blackweel, London-NY (1992)

5. L. Argote , H. Greve, A Behavioral Theory of the Firm - 40 Years and Counting: Introduction and Impact. Organization Science, 18(3), 337-349 (2007)

6. W. Samuelson, S. Marks, Managerial Economics. Wiley, London-NY (2014)

7. S. Landsg, Price Theory and Applications. Cengage Learning, Boston, MA (2013)

8. R. Schindler, Pricing Strategies: A Marketing Approach. SAGE Publications, London (2011) 
9. P. Van Westendorp, NSS-Price Sensitivity Meter (PSM) - A new approach to study consumer perception of price. Proceedings of the 29th ESOMAR Congress, Venice, Italy 22-30 (1976)

10. J. Hess, E. Gerstner, Loss Leader Pricing and Rain Check Policy. Marketing Science 6, $1-18(2001)$

11. N. Shpak, N. Seliuchenko, V. Kharchuk, N. Kosar, Wł. Sroka, Evaluation of Product Competitiveness: A Case Study Analysis. Organizacija, 52(2), 107-125 (2019)

12. G. S. Becker, Human Behavior: Economical Approach. Selected Works on Economic Theory. SU HSE, Moscow (2003) [in Rus.]

13. R. H. Thaler, Misbehaving: The Making of Behavioral Economics. W. W. Norton \& Company, NY (2015)

14. D. Kahneman, A. Tversky, Choices, Values and Frames. Cambridge University Press, New York (2000)

15. C. Mirică, The behavioral economics of decision making: Explaining consumer choice in terms of neural events. Economics, Management, and Financial Markets, 14(1), 15-20 (2019)

16. S. Starov, Brand management. Graduate School of Management, St. Petersburg (2015) [in Rus.]

17. E. Spiridonova, Innovation management. Urite, Moscow (2018) [in Rus.]

18. E. Spiridonova, Franchising. St. Petersburg University Press, St. Petersburg (2010) [in Rus.]

19. The portal "101 business plan", Information message [online]. Available at: http://101biznesplan.ru/spravochnik-predprinimatelya/terminy-i-ponyatiya/kakpravilno-delat-natsenku-na-tovar.html (2019)

20. Information portal Trud.com [online]. Available at: https://sankt-peterburg.trud.com /salary/865.html (2019)

21. "SpetsHlebMash" plant portal [online]. Available at: http://www.int.nsk.su/phe-2503.php (2019)

22. Catalogs goods supermarket chain "Okay" (Date of contact: April 2, 2019) Available at: https://www.okmarket.ru/ customers/catalogs/ (2019)

23. Catalog of supermarkets "Polushka" (Date of contact: April 2, 2019) Available at: http://www.a-piter.ru/cena/polushka_skidki.html (2019)

24. Ltd. "Prism" - catalog (Date of contact: April 2, 2019) Available at: http://tomall.ru/allmarket/prisma (2019)

25. Revenues and expenses of a mini-bakery (Date of contact: April 4, 2019) Available at: http://biz911.net/organizatsiya-biznesa/dokhody-i-raskhody-biznesa/dokhody-iraskhody-mini-pekarni/ (2019)

26. Bread prices in Russia were overstated 10 times (Date of contact: April 4, 2019) Available at: https://www.mk.ru/economics/2016/09/07/ceny-na-khleb-v-rossiiokazalis-zavysheny-v-10-raz.html (2019)

27. L. Gajanova, M. Nadanyiova, D. Moravcikova, The Use of Demographic and Psychographic Segmentation to Creating Marketing Strategy of Brand Loyalty. Scientific annals of economics and business 66, 1, 65-84 (2019)

28. J. Majerova, T. Kliestik, Brand valuation as an immanent component of brand value building and managing. In 4th World Conference on Business, Economics and Management (WCBEM) (Ephesus, Turkey, 546-552, 2015) 
29. J. Majerova, Analysis of Specifics in Buying Behavior of Slovak Customers in Internet Environment. In 2nd International Conference on Social Sciences Research (Hong Kong, China, 172-178, 2014)

30. W. Sroka, M. Lorinczy, The Perception of Ethics in Business: Analysis of Research Results. Procedia Economics and Finance 34, 156-163 (2015) 